\title{
Analisis Faktor Penggunaan Dompet Digital Studi Kasus di Kota Surabaya
}

\author{
Daniel Hartono Wibowo Chandra ${ }^{1}$, Julius Mulyono ${ }^{2 *}$, Ig. Jaka Mulyana ${ }^{3}$, Yohanes Sudaryanto ${ }^{4}$ \\ 1,2,3Program Studi Teknik Industri, Fakultas Teknik, Universitas Katolik Widya Mandala, Surabaya, Indonesia \\ ${ }^{4}$ Program Studi Teknik Kimia, Fakultas Teknik, Universitas Katolik Widya Mandala, Surabaya, Indonesia \\ ( ${ }^{*}$ juliusnyamulyono@ukwms.ac.id)
}

\begin{abstract}
Abstrak-Perkembangan teknologi menuntut segala sesuatu dilakukan serba cepat, praktis, dan efektif efisien. Hadirnya dompet digital menggunakan sistem elektronik berbasis internet, sistem kerja dapat meringkas segala transaksi keuangan dibandingkan dengan transaksi konvensional. Penelitian ini menganalisis faktor-faktor yang mempengaruhi pemilihan penggunaan dompet digital di Kota Surabaya, dengan melakukan analisis cluster pada profil responden yang didapat dan analisis diskriminan untuk menemukan perbedaan tiap cluster. Dilakukan analisis faktor dari variabel-variabel yang telah ditentukan sehingga didapatkan hasil kemudahan, kemampuan finansial, kecepatan bertransaksi, keamanan, promosi, dan pengaruh sosial berpengaruh terhadap pemilihan penggunaan dompet digital. Terbentuk 2 cluster responden, sedangkan yang menjadi pembeda adalah tingkat penghasilan oleh konsumen.
\end{abstract}

Kata kunci: analisis cluster; analisis faktor; dompet digital; kemampuan finansial; kemudahan

\section{PENDAHULUAN}

Pada jaman modern ini, segala sesuatu semakin canggih, khususnya terkait dengan teknologi informasi dan komunikasi. Dalam kehidupan sehari-hari, semua kegiatan berhubungan dengan modernisasi, menggunakan kemajuan teknologi yang semakin canggih. Hal ini juga terlihat dalam proses transaksi jualbeli, tidak hanya oleh perusahaan, tetapi juga oleh masyarakat umum. Masyarakat mengadakan transaksi pembayaran atau belanja secara digital, selain konvensional. Dompet digital atau e-wallet adalah salah satu bentuk kemajuan teknologi dalam proses transaksi belanja/pembayaran yang ditawarkan kepada masyarakat. Selayaknya aplikasi teknologi lainnya, fitur-fitur yang ditawarkan adalah kemudahan proses pembayaran, praktis, kecepatan transaksi, keamanan; sehingga sangat menunjang efisiensi dan meningkatkan efektivitas. Aplikasi ini tidak mensyaratkan sesuatu yang sulit, cukup dengan menggunakan smartphone yang ada di pasaran. Smartphone sangat mendukung bermacam-macam proses, selain komunikasi. Menurut Amoroso, $e$ wallet atau dompet digital melakukan transaksi secara elektronik, bukan konvensional dengan uang sebagai alat tukar/pembayaran. Oleh karena itu, e-wallet termasuk mobile payment kategori electronic wallet. Proses transaksi dilakukan tanpa menggunakan barang fisik (kartu debit dll), namun sepenuhnya secara elektronik. Sedangkan Sahut lebih memperhatikan bahwa $e$-wallet mengurangi/meniadakan peran uang tunai (kas) dalam kaitannya dengan keamanan, yaitu terjatuh/kehilangan uang karena penyimpanan kurang aman, bahkan terjadinya kehilangan karena pencurian uang. Tentu saja, faktor kemudahan dan kecepatan transaksi juga berbeda dengan penggunaan uang konvensional. Siti, 2016, memberikan pendapat mengenai $e$-wallet dengan memperhatikan detil proses transaksi/pembayaran yang mencakup proses pengembalian. Seringkali penjual harus menyediakan uang pengembalian yang belum tentu siap setiap waktu. Proses pengembalian kelebihan bayar ini sangat signifikan, dalam sudaut pandang waktu transaksi yang diperlukan. Hal ini akan bertambah menarik, ketika ketersediaan uang pengembalian berupa uang recehan, yang seringkali kurang disukai terkait penyimpanan di dompet konvensional, tidak seperti uang kertas.

Susanto mengamati penggunaan e-wallet adalah bagian dari praktek sehari-hari yang mendukung terbentuknya cash less society. Berdasarkan data Kuartal II 2019 yang didapatkan dari App Annie, 5 besar aplikasi $e$-wallet dengan pengguna paling aktif bulanan terbanyak diduduki oleh pemain lokal yaitu Go-Pay, OVO, DANA, LinkAja, dan Jenius. Hasil Survey pengguna dompet digital 2020 berdasarkan data laporan dari Ipsos berjudul "The Evolution of the Digital Wallet: Driving the Next Wave of Growth" yang dilansir 12 Februari 2020 mengungkap bahwa pengguna dompet digital sudah cenderung menganggap $e$-wallet adalah sesuatu yang tidak terpisahkan dalam kehidupan sehari-hari. Dari survey yang dilakukan oleh Ipsos, diketahui bahwa sebagian besar pengguna dompet digital adalah generasi muda dengan kemampuan bayar. Rentang usia pengguna dompet digital terbanyak yaitu 25-40 tahun. Rentang usia tersebut paling sering melakukan pengisian (top-up) saldo untuk dompet digital adalah pengguna usia 25-29 tahun, dan usia yang lebih tua cenderung untuk mengisi saldo lebih sedikit. 


\section{STUDI LITERATUR}

Dompet elektronik adalah suatu metode pembayaran terbaru di Indonesia. Menurut Peraturan Bank Indonesia Nomor 18/40/PBI/2016 tentang Penyelenggaraan Pemrosesan Transaksi Pembayaran, Electronic Wallet atau dompet elektronik adalah layanan elektronik untuk menyimpan data instrumen pembayaran antara lain alat pembayaran dengan menggunakan kartu dan/atau uang elektronik, yang dapat juga menampung dana, untuk melakukan pembayaran. Dompet elektronik biasa disebut dengan istilah $e$-wallet, dompet digital, digital wallet atau electronic wallet. Penyelenggara dompet elektronik adalah bank atau lembaga selain bank yang menyelenggarakan dompet elektronik Indonesia. Untuk bisa mengakses layanan dompet digital, pengguna harus memasang aplikasi dompet digital pada smartphone mereka. Saat pendaftaran akun, pengguna akan diminta mengisi data lengkap yang meliputi nama, alamat, informasi kartu, dan lain-lain. Semua riwayat transaksi akan disimpan di dalam aplikasi, sehingga memudahkan pengguna jika ingin memeriksanya kembali. Layanan dompet digital terjamin aman. Pada setiap transaksi, pengguna akan diminta melakukan pemindaian QR Code atau memasukkan kode One Time Password (OTP) yang dikirimkan pada nomor handphone terdaftar dan memasukan pin yang didaftarkan. Langkah tersebut merupakan verifikasi, sehingga tidak ada orang lain yang menyalahgunakan penggunaan aplikasi tersebut. Selain itu, dengan adanya dompet digital pengguna tidak perlu membawa uang tunai dalam jumlah banyak. Cukup berbekal smartphone dan mengisi saldo yang cukup pada dompet digital, maka pengguna bebas melakukan transaksi kapan saja dan dimana saja.

Sistem pembayaran telah berubah sepanjang waktu, demikian pula dengan bentuk uang. Definisi transaksi secara sederhana dapat diartikan sesuatu kegiatan menjual atau membeli. Sehingga dapat disimpulkan sistem pembayaran transaksi adalah suatu sistem pemindahan dana/uang atas kegiatan jual beli barang/jasa.

\section{METODOLOGI}

Pada tahap ini data dikelompokan berdasarkan kriteria yang ditentukan selanjutnya pengujian validitas menggunakan analisa korelasi bivariate. Prakuesioner dan kuesioner dikatakan valid apabila memiliki nilai probabilitas korelasi dibawah nilai signifikansi yaitu sebesar 0,05 . Uji reliabilitas diukur dengan menggunakan Cronbach's alpha yang digunakan untuk menilai konsistensi hasil dari pengukuran. Hasil pengukuran disebut reliabel jika diperoleh nilai Cronbach's alpha diatas 0,6. Pengujian validitas maupun realibitas dilakukan dengan menggunakan software SPSS. Apabila setelah dilakukan uji hasilnya tidak valid dan reliabel pada prakuesioner, maka dilakukan penyebaran prakuesioner kembali. Jika kuesioner ulang belum valid dan reliabel maka dapat dilakukan dengan menambah responden baru dan membuang hasil error yang paling tinggi pada responden. Uji validitas dilakukan dengan:

$$
r=\frac{n \sum X Y-\sum X \sum Y}{\sqrt{\left\{n \sum X^{2}-\left(\sum X\right)^{2}\right\}\left\{n \sum Y^{2}-\left(\sum Y\right)^{2}\right\}}}
$$

dengan:

$\mathrm{r}=$ Korelasi

$\mathrm{Y}=$ Skor total dikurangi item tersebut

$\mathrm{X}=$ Skor setiap item

$\mathrm{n}=$ Ukuran sampel

Uji Reliabilitas dapat dilakukan perhitungan sebagai berikut:

$$
\alpha=\left(\frac{k}{k-1}\right)\left(1-\frac{\sum \sigma_{b}^{2}}{\sigma_{t}^{2}}\right)
$$

$\alpha \quad=$ Koefisien realibilitas Cronbach's Alpha

$\sum \sigma_{b}^{2}=$ Jumlah varians tiap item pernyataan $\mathrm{k} \quad=$ Banyaknya item pernyataan

$\sigma_{\mathrm{t}}^{2}=$ Varians total

Analisis faktor mencoba menemukan hubungan (interrelationship) antara sejumlah variabel yang saling independen, sehingga bisa membuat satu atau beberapa kumpulan variabel yang lebih sedikit. Faktor harus tetap dapat mencerminkan variabel-variabel aslinya. Analisis cluster akan menghasilkan sejumlah kluster (kelompok). Analisis ini diawali dengan pemahaman bahwa sejumlah data tertentu sebenarnya memiliki 
kemiripan di antara anggotanya. Analisis Diskriminan adalah teknik multivariat yang termasuk pada Dependence Method, dengan ciri adanya variabel dependen dan independen. Ada variabel yang hasilnya tergantung pada data variabel independen. Ciri khusus analisis diskriminan adalah data variabel dependen harus berupa data kategori, sedangkan data untuk variabel independent justru berupa data rasio.

\section{HASIL DAN PEMBAHASAN}

Penelitian ini dilakukan 10 Febuari - 24 Maret 2020 menggunakan sampling judgement, responden telah ditentukan sebelumnya yaitu responden yang mempunyai dompet digital di wilayah Surabaya meliputi wilayah Surabaya bagian Utara, Timur, Selatan, Barat Pusat. Data yang dikumpulkan secara kuesioner untuk melakukan prakuesioner sebanyak 30 data, dari jumlah kuesioner yang dikehendaki yaitu sebanyak 200 data. Secara garis besar kuesioner dibagi menjadi dua bagian yaitu: profil responden serta tanggapan tentang penggunaan dompet digital. Dilakukan pengujian validitas dan reliabilitas.

Selanjutnya dilakukan penyebaran 200 kuesioner. Pengujian validitas kuesioner menunjukkan semua variabel mengenai tingkat angka Significance (2-tailed) yang secara keseluruhan berada di bawah 0,05 serta nilai Pearson Correlation yang bernilai positif dan bernilai lebih dari nilai 0,138 yang didapat dari nilai $\mathrm{r}$ Product Moment dengan ukuran sampel 200 serta alfa 5\%, sehingga seluruh variabel faktor kemudahan, keamanan dan kemampuan finansial dapat digunakan. Pengujian reliabilitas kuesioner didapatkan bahwa semua variabel pada kuesioner mempunyai nilai Cronbach's Alpha lebih dari 0,6. Dari hasil tersebut, dapat diketahui bahwa pertanyaan-pertanyaan (variabel) pada kuesioner telah reliabel.

Analisis dekriptif profil responden, usia pengguna dompet digital mayoritas antara 17-24 (49\%). Responden mayoritas 53\% laki-laki dan $47 \%$ perempuan. Berdasarkan tempat tinggal mayoritas tinggal di daerah Surabaya Barat (23\%). Berdasarkan rata-rata pendapatan per bulan mayoritas kurang dari 3 juta rupiah (45\%). Berdasarkan pekerjaan adalah mahasiswa/pelajar (40\%). Berdasarkan cara bertransaksi mayoritas menggunakan uang dalam dompet digital (73\%) sedangkan $27 \%$ responden menggunakan uang tunai. Berdasarkan jenis dompet digital mayoritas menggunakan Ovo (32\%) dan Gopay (27\%). Berdasarkan seberapa sering menggunakan dompet digital, responden dalam sebulan menggunakan 5-9 kali (33\%). Jumlah pembelanjaan tiap bulan menggunakan dompet digital antara Rp. 200.000 - Rp. 500.000. Penggunaan dompet digital untuk melakukan pembelian makanan/minuman (21\%), selain itu juga digunakan untuk belanja toko online, transportasi, tagihan, dll. Keinginan menggunakan dompet digital mayoritas karena adanya cashback (22\%), promo (20\%), dll.

Tujuan dari Analisis Faktor adalah menemukan keterkaitan variabel-variabel yang saling bebas satu dengan yang lain sehingga dapat dibuat satu atau beberapa kumpulan variabel yang lebih sedikit dari jumlah variabel awal. 


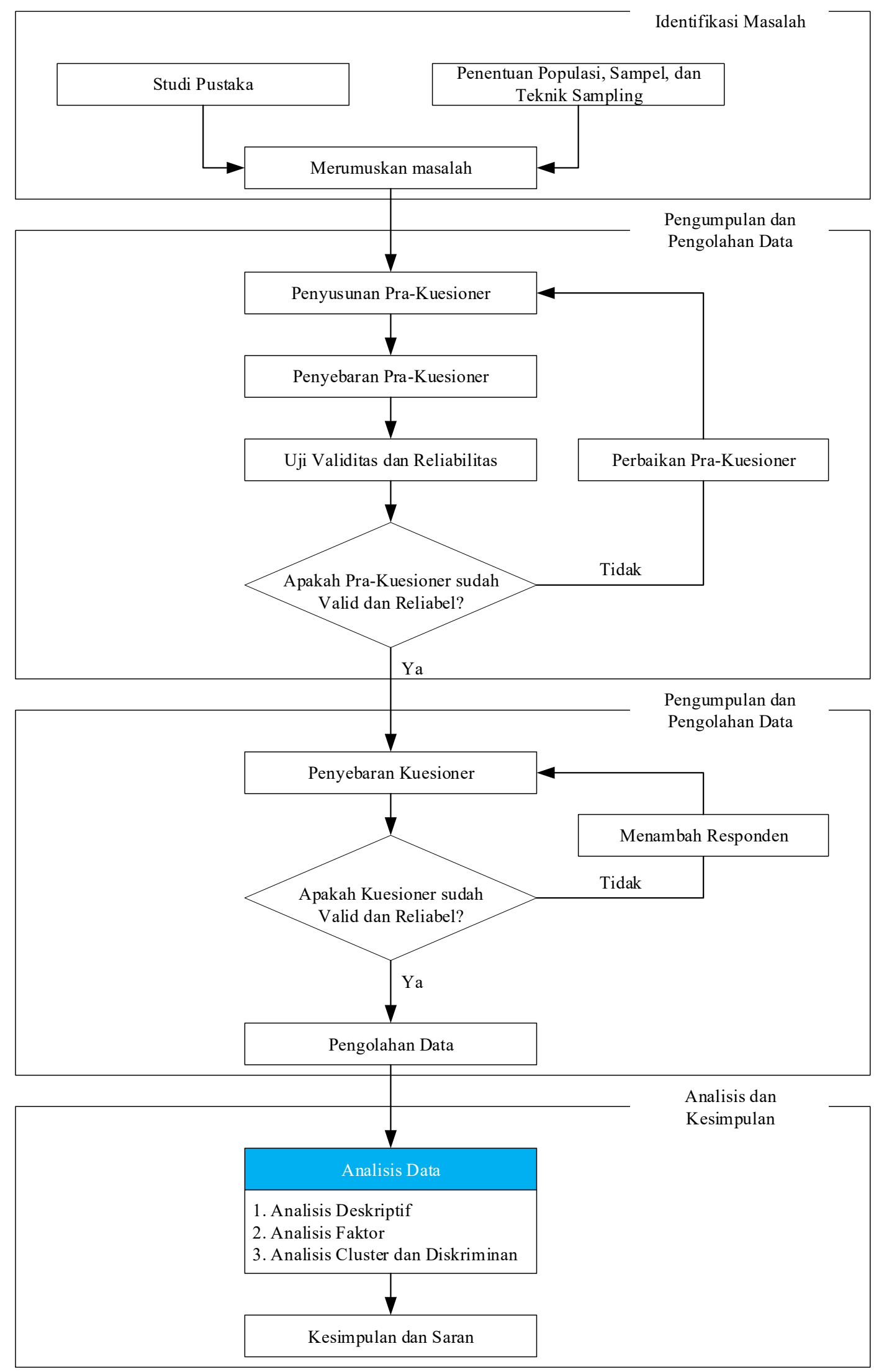

Tabel 1 berisi nilai Eigen sama dengan atau lebih dari 1 pada 7 faktor yang terbentuk untuk mewakili seluruh variabel yang ada. Sebesar $59.801 \%$ variabel faktor pendukung responden yang menggunakan dompet digital dapat dijelaskan oleh ketujuh variabel yang terbentuk. Sedangkan sisanya sebesar $(100 \%-59,801 \%=$ 40,199 \%) dijelaskan oleh faktor yang lain. Pada faktor-faktor di atas, terbentuk berdasarkan tingkat hubungan 
atau variabel dengan nilai kolerasi terbesar, maka diperoleh hasil: Berawal 22 faktor berkurang menjadi 7 faktor yang mewakili seluruh variabel yang ada. Berikut merupakan faktor-faktor yang telah terbentuk melalui proses analisa faktor, kemudian diberi nama sesuai dengan karakteristik yang sesuai dengan faktor-faktor anggotanya.

Tabel 1

Tabel Total Variance Explained

\begin{tabular}{|c|c|r|r|r|r|c|}
\hline \multirow{2}{*}{ Component } & \multicolumn{3}{|c|}{ Initial Eigenvalues } & \multicolumn{3}{c|}{$\begin{array}{c}\text { Rotation Sums of Squared } \\
\text { Loadings }\end{array}$} \\
\cline { 2 - 7 } & Total & $\begin{array}{c}\text { \% of } \\
\text { Variance }\end{array}$ & $\begin{array}{c}\text { Cumulative } \\
\%\end{array}$ & Total & $\begin{array}{c}\% \text { of } \\
\text { Variance }\end{array}$ & $\begin{array}{c}\text { Cumulative } \\
\%\end{array}$ \\
\hline 1 & 4.568 & 20.763 & 20.763 & 2.320 & 10.545 & 10.545 \\
2 & 1.936 & 8.802 & 29.565 & 2.200 & 9.999 & 20.545 \\
3 & 1.665 & 7.568 & 37.132 & 2.190 & 9.954 & 30.499 \\
4 & 1.441 & 6.548 & 43.681 & 1.931 & 8.778 & 39.277 \\
5 & 1.295 & 5.886 & 49.567 & 1.625 & 7.386 & 46.663 \\
6 & 1.151 & 5.232 & 54.798 & 1.467 & 6.668 & 53.332 \\
7 & 1.101 & 5.003 & 59.801 & 1.423 & 6.470 & 59.801 \\
\hline
\end{tabular}

Tabel 2

\begin{tabular}{|l|l|}
\hline 1 & $\mathrm{~A} 1, \mathrm{~A} 2, \mathrm{~A} 3, \mathrm{~A} 4$ \\
\hline 2 & $\mathrm{C} 1, \mathrm{C} 3, \mathrm{C} 4, \mathrm{D} 6$ \\
\hline 3 & $\mathrm{D} 7, \mathrm{D} 8, \mathrm{D} 9$ \\
\hline
\end{tabular}

Rotated Component Matrix

\begin{tabular}{|l|l|}
\hline 4 & $\mathrm{~B} 1, \mathrm{~B} 2, \mathrm{~B} 3, \mathrm{~B} 4$ \\
\hline 5 & $\mathrm{C} 5, \mathrm{D} 1, \mathrm{D} 2$ \\
\hline 6 & $\mathrm{D} 3, \mathrm{D} 4$ \\
\hline
\end{tabular}

Faktor pertama terdiri dari mudah dipahami dan digunakan, praktis tidak bingung kembalian, banyak merchant yang transaksi pembayarannya menggunakan dompet digital, dapat diakses mudah di kota Surabaya Maka dari itu faktor ini akan dinamakan sebagai faktor kemudahan. Faktor kedua terdiri dari tingkat keseringan menggunakan dompet digital, penghasilan setiap bulan mampu untuk mengisi ulang dompet digital, ketika memiliki tanggungan biaya lain penghasilan saya mencukupi untuk mengisi dompet digital, menggunakan dompet digital yang mudah mengisi saldonya. Maka dari itu faktor ini akan dinamakan sebagai faktor kemampuan finansial. Faktor ketiga terdiri dari memilih dompet digital yang mudah ditarik saldonya, memilih dompet digital yang cara transfer sesama pengguna mudah, memilih dompet digital yang mentransfer ke rekening bank mudah. Maka dari itu faktor ini akan dinamakan sebagai faktor kecepatan bertransaksi. Faktor keempat terdiri dari transaksi dengan kode pin dan OTP(One-Time Password $)$, transaksi menggunakan QRCode lebih aman dan cepat, jaminan saldo pada dompet digital, menggunakan dompet digital yang diawasi oleh penyelenggara yang terpercaya. Maka dari itu faktor ini akan dinamakan sebagai faktor pengaruh keamanan. Faktor kelima terdiri ada pencatatan pembayaran yang lebih baik, menggunakan dompet digital karena menawarkan banyak promo/ diskon/cashback, pembayaran transaksi dompet digital lebih efisien dibandingkan tunai. Maka dari itu faktor ini akan dinamakan sebagai faktor pengaruh promosi. Faktor keenam terdiri pembayaran transaksi dompet digital lebih efisien dibandingkan debet/credit card, lingkungan sosial saya mempengaruhi untuk menggunakan dompet sosial. Maka dari itu faktor ini akan dinamakan sebagai faktor pengaruh sosial. Faktor ketujuh akan direduksi karena faktor yang terbentuk tidak sesuai dengan kriteria, karena hanya memiliki hanya satu anggota, dan penamaan yang tidak tepat karena anggotanya tersebar dari beberapa faktor yang terpisah sehingga penamaan tidak akan bisa mewakili karakteristik dari anggota faktor tesebut. Sehingga faktor ketujuh ini hanya terdiri dari dengan menggunakan dompet digital menyebabkan pengeluaran yang tidak terencana, belanja cuma membawa smartphone (cashless).

Analisis cluster bertujuan untuk membuat cluster (pengelompokan) berdasarkan karakteristik yang memiliki kemiripan variabel tertentu. Pada tahap ini dipakai analisis hierarchical method untuk 
menggambarkan pengelompokan responden dengan menggunakan dendrogram berdasarkan hasil data responden yang didapat dari kuesioner. Variabel-varibel yang digunakan pada profil responden antara lain usia responden, jenis kelamin, status, tempat tinggal, pendapatan per bulan, pekerjaan, bertransaksi membayar dengan, seberapa sering dompet digital digunakan, jumlah pembelanjaan menggunakan dompet digital, dan besaran top-up.

Tabel 3

Tabel Rekapitulasi Cluster dari Hasil Crosstab Pertanyaan Rekap Data

\begin{tabular}{|l|l|}
\hline \multicolumn{1}{|c|}{ Cluster 1 } & \multicolumn{1}{c|}{ Cluster 2 } \\
\hline Pada cluster 1 didominasi dengan usia 33 Tahun & Pada cluster 2 didominasi dengan usia 17 Tahun \\
sampai dengan 40 Tahun dengan jenis kelamin laki- & sampai dengan 24 Tahun dengan jenis kelamin laki- \\
laki dan perempuan, dengan status sudah berkeluarga, \\
pekerjaan wiraswasta, yang bertempat tinggal di \\
Surabaya Utara.
\end{tabular}

Analisis diskriminan bertujuan untuk mengetahui perbedaan yang jelas antar group pada variabel dependen, untuk mengetahui variabel independen yang membuat perbedaan yang signifikan dari tiap karakteristik cluster yang ada. Setelah dilakukan uji korelasi variabel bebas terdapat variabel yang berbeda secara signifikan yaitu variabel C4 memiliki nilai signifikan kurang dari 0,05 yaitu 0,034 yang berarti data dapat dilakukan analisis lebih lanjut karena terdapat variabel yang berbeda secara signifikan.

Tabel 4

Canonical Discriminant Function Coefficients

\begin{tabular}{|l|c|}
\hline \multirow{2}{*}{} & Function \\
\cline { 2 - 2 } & 1 \\
\hline C4 & 1.510 \\
(Constant) & -4.583 \\
\hline
\end{tabular}

Hanya terdapat variabel $\mathrm{C} 4$ yang dapat digunakan untuk mengidentifikasi perbedaan antar-group. Sehingga dapat dirumus untuk menghitung Zscore yaitu:

$$
\text { Zscore }=(-4,583)+(1,510 \times \mathrm{C} 4)
$$

Setelah itu perhitungan nilai angka kritis yang berfungsi sebagai cut off score dapat dilihat dari Tabel 5.

Tabel 5

Nilai Centroid

\begin{tabular}{|l|c|c|}
\hline \multirow{2}{*}{ Cluster } & Function & \multirow{2}{*}{$\mathrm{N}$} \\
\cline { 2 - 2 } \multicolumn{1}{c|}{ kaum dewasa } & 1 & \\
kaum muda & -.195 & 73 \\
kaum & -112 & 127 \\
\hline
\end{tabular}

Perhitungan titik potong: $\quad Z c u=\frac{(73 \times(-\mathbf{0 , 1 1 2}))+(\mathbf{1 2 7} \times \mathbf{0 , 1 9 5})}{(\mathbf{7 3 + 1 2 7})}=0,082945$

Hal ini berarti titik cutoff kedua cluster adalah 0,082945. Apabila ada responden baru yang memiliki nilai Zscore di atas -0,082945 maka responden tersebut masuk dalam cluster 2, begitu juga bila ada responden baru yang memiliki nilai Zscore di bawah 0,082945 maka responden tersebut masuk dalam cluster 1. 


\section{KESIMPULAN}

Setelah melakukan pengolahan dan analisis data, berikut adalah kesimpulan yang dihasilkan:

1. Keenam faktor berikut: Kemudahan, kemampuan finansial, kecepatan bertransaksi, keamanan, promosi dan pengaruh sosial berpengaruh secara signifikan terhadap pemilihan penggunaan dompet digital.

2. Terbentuk 2 cluster pengguna dompet digital. Pertama bernama cluster kaum dewasa karena memiliki umur 33-40 tahun dan sudah bekerja. Kedua, cluster kaum muda karena mayoritas memiliki usia 17-24 tahun dan seorang pelajar/mahasiswa.

3. Pada analisis crosstab pemilihan dompet digital yang diuji berpengaruh terhadap usia, status, tempat tinggal, pendapatan per bulan, pekerjaan, sering dompet digital digunakan, jumlah pembelanjaan dan besaran top-up dompet digital.

4. Responden lebih banyak memilih dompet digital Ovo dan Go-pay. Alasan responden memilih karena terdapat cashback dan promosi yang ditawarkan.

\section{DAFTAR PUSTAKA}

Amaroso, D.L.(2011). Building A Research Model For Mobile Wallet Consumer Adoption. Jurnal Of Theoretical And Applied Electronic Commerce Research, 7 (1),94-110.

Sahut, J. M. (2008). The Adoption and Diffusion of Electronic Wallets: The Case Of Moneo. Journal of Internet Banking and Commerce, 1-10.

Hidayati, Siti dkk. (2006). Operasional E-money. Jakarta: Bank Indonesia.

Susanto, Arif. (2009). Era Uang Elektronik di Depan Mata. Tersedia di http://www.bisnis.com/servlet/page?_pageid=127\&_dad=portal30\&_schema=PORTAL. [Online] [Accessed: Febuari. 12,2020]

https://www.liputan6.com/bisnis/read/4037468/daftar-e-wallet-terpopuler-di-indonesia-dana-raih-penggunaaktif-terbanyak. . [Online] [Accessed: Maret. 03,2020]

Ipsos. (2020). The Evolution of the Digital Wallet: Driving the Next Wave of Growth.

Tersedia di https://www.ipsos.com/sites/default/files/ct/news/documents/2020-02/ipsos_-_press_release__english.pdf. [Online] [Accessed: Mei. 16,2020]

Indonesia, Bank. (2016). PBI 18/40/PBI/2016 Penyelenggaraan Pemrosesan Transaksi Pembayaran. Tersedia http://www.bi.go.id/id/peraturan/sistempembayaran/Documents/ PBI_184016.pdf. [Online] [Accessed: Desember. 29,2019]

Frederic, Mishkin. (2008). Subprime Crisis Preview Chapter for the Economics of Money, Banking, and Financial Markets. Columbia University.

Ghozali, I. (2002). Aplikasi Analisis Multivariate Dengan Program SPSS. Semarang: Badan Penerbit UNDIP. Sugiyono. (2010). Statistika untuk Penelitian. Bandung: Alfabeta. Bandung: Alfabeta

Santoso, S. (2015). Menguasai Statistik Multivariat. Jakarta: PT Elex Media Komputindo. 